\title{
STUDY ON 100\% ENERGY EFFICIENT SUSTAINABLE BUILDINGS
}

\author{
Ashish V Zade ${ }^{1}$, Sanyukta R Arvikar ${ }^{2}$, Ruchita R Shetty ${ }^{\mathbf{3}}$, Harshal P Kapse ${ }^{\mathbf{4}}$, U.J.Phatak ${ }^{\mathbf{5}}$ \\ 1, 2, 3,4 B.E Civil, J.S.P.M's Imperial College of Engineering and Research, Wagholi, Pune, India. \\ ${ }_{5}^{5}$ Assistant Professor, J.S.P.M's Imperial College of Engineering and Research, Wagholi, Pune
}

\begin{abstract}
This paper addresses the approach to minimize the Energy consumption and the cost of house and it givesthe comfort to the people living within. This can be achieved by proper design of the structure and use of renewable resources. Energy can be harnessed on site by use of solar for energy production which can be further stored for consumption in absence of daylight.

For achieving zero energy houses first we need to conserve energy at the time of construction and the execution then create energy by renewable resources. Hence the amount of energy required for proper working in created on site hence there is no need for any external source of energy. A zero energy home guarantees long term energy and cost stability for the homeowner. The aim of the present study is to develop an open-access, consistent database of both personified energy and carbon for construction materials.
\end{abstract}

Keywords: Energy, Energy saving, Cost saving, Emission reduction

\section{INTRODUCTION}

The economic growth of the country or the state is generally due to the construction industry. This development generally consist of, infrastructure, residential, commercial, recreational and etc. the mostly used method of construction, is the conventional type. This are also called as concrete jungles which has many disadvantages such as deforestation, cutting the road side trees, air pollution, water pollution, noise pollution, etc. for curing the concrete lot of water is wasted. The cement which is used in construction causes pollution at the time of its production it releases $\mathrm{CO}^{2}$ and Greenhouse gases which further enhance the global warming.

The power generation which is eco-friendly by hydro-power plant but other plant such as thermal power plant and nuclear which creates lot of air pollution. The dumping of the waste pollutes the dumping land and the treatment of sewage generally pollutes the river.

Now days the cities are suffering from the shortage of water supply and the air pollution is increased. Delhi is said to be a dead air city where the pollution has gone beyond the safe limits. This directly affects the humans and they suffer from such serious health problems. Due to increase in the global warming and the greenhouse effect there are season shifting or climatic changes occurs.

To overcome from such problem the method of the construction should be changed by keeping in view that any activity would not affect the nature. To reduce the emission, carbon foot prints the newly introduced technique is to make the house or building to produce the required energy and other means on site only. The air pollution can be reduced, No wastage of water, no waste product, etc. these type of house or building can help in saving the environment.
The building can produce electricity by the PV cell; during the rainy season the building can harvest the water which is charged to increase the water table. The waste water is used for gardening; the sewage is made fertilizers by digesters so no waste product is produced. The materials used for construction are also the eco-friendly material which has enough strength to withstand the earthquake, and has a life of more than 80 years, so the goal of the building is to overcome the conventional techniques.

The $100 \%$ efficient building was not really expected to take; the challenge was to minimize all the usage of the building and to minimize the waste to zero and other technique and technology to make the efficient but all the requirements were fulfilled so the this building was found out to be $100 \%$ efficient building.

By accepting these technology and new method of construction the problems related to the construction sector can be solved.

\section{OBJECTIVES}

To minimize the cost associated with building energy consumption is the first objective of zero energy building. The main purpose to study zero energy building concept is to understand energy saving and sustainable housing. The main objectives focused in the project are the benefits of energy efficiency in building, to understand the methodology used to determine the efficiency of ZEB, Therefore, the main aim of this study is:

1. Study the need of zero energy building concept.

2. Study of various techniques used to achieve zero energy building construction.

3. Study of materials used in the zero energy building construction.

4. Study and analysis of energy consumption by conventional method and zero energy method and check its suitability. 


\section{SCOPE OF STUDY}

This paper will review someof the available efficiency promoting technologies as well as renewable energy generation technologies that can be utilized to construct zero net energy building. In addition the economic viability of zero energy buildings will be examined. A zero energy building focuses firstly on energy efficiency, and then on use of renewable energy sources on site. The study of zero energy building focuses on the need for this new concept and energy analysis of the building built by using this technique. It also deals with the advantages of adopting the zero energy building concept and its suitability in different regions.

\section{LITERATURE REVIEW}

\section{1. "Redefining Net Zero Energy: Renewable Energy}

Balance in environmental building design",

\section{Elsevier.}

Author finds that development of a method to assess the Renewable Energy Balance of a building. He finds that these buildings encourage a high standard of sustainability by enhancing the use of renewable resources over the entire life cycle of the building from "formation-extractionmanufacturing" to "maintenance and operation". $\mathrm{He}$ maximizes the use of renewable resource by replacing all non-renewable resources with renewable resources, thereby contributing to the overall sustainability of the geobiosphere.

\section{2. "Bounded socio-technical experiments as agents}

\section{of systemic change: The case of a zero-energy}

\section{residential building", Elsevier}

The paper focuses on development of the methods to determine the maximum renewable energy potential for buildings. The author reveals the various forms and advantages of green energy construction. Author finds that the uses of renewable resources are more economical. Author focuses on use of new techniques of construction to meet social needs. Participation by various professional groups who bring different perspectives to the process

\section{3. "UNDERSTANDING ZERO ENERGY BUILDINGS", ASHRAE JOURNAL, SEPTEMBER 2006}

The author suggests change on how buildings use energy, to the point of creating ZEBs in the coming years.He also stated that we all need to try to achieve this goal and help simplify decisions that are economically responsible, environmentally sound, aesthetically pleasing, and occupant friendly.He suggested that we need to work on how to create low-energy buildings. Constructing market-viable buildings that use significantly less energy is possible today.

\section{RESEARCH METHODOLOGY}

The methodology adopted for present study is to study the Zero energy concept, its need why it should be adopted and the advantages behind the study. The various techniques used for construction of such forms should be studied. The main aim behind this study is the use of renewable resources for energy production hence the energy should be harnessed on site with maximum efficiency. Thus, by replacing nonrenewable resources with Renewable Substitutability with renewableresources over the building's life-time, a state of Renewable EnergyBalance is approached. The energy usage should be reduces by proper design of the structure. Energy saving appliances should be used for the efficient use of the energy.

\section{RESULTS AND DISCUSSION}

Analysis is done on site data:

Site- Solar City,Ratnagiri.

This data will help to determine the research basis and direction. Reviews of other works from literature survey will become the backbone of this research. Comparison of Zero energy building with conventional building.

Time Reduction

\begin{tabular}{|l|l|l|}
\hline Sr no & Conventional & ZEB \\
\hline 1 & - & $\mathbf{3 8 . 5 2 \%}$ \\
\hline
\end{tabular}

Cost Reduction

\begin{tabular}{|l|l|l|l|l|}
\hline Sr no & Parameter & Conventional & ZEB & \% Reduction \\
\hline 1 & Lighting & 315 units/rs 2702.63 & 105 units/rs558.1 & 66.66 \\
\hline 2 & Cooling & 32412.2 units/rs 27777.08 & 1051.2 units/rs9008.78 & $\mathbf{7 3 . 1 2}$ \\
\hline
\end{tabular}

\section{CONCLUSION}

From above study we conclude that,

1. The zero energy concepthas a wide scope in our industry hence it should be adopted globally.

2. It proves economical in long run though it has a moderately high initial cost.
3. It is totally self-dependent and requires zero maintenance and reduces energy bills.

4. It is not only benefic the consumer but also serves a helping hand for the environment and reduces the carbon footprints. 


\section{REFERENCES}

[1]. Kirsten Voss, EikeMusall, and Markus Lichtme, "FROM LOW-ENERGY TO NET ZERO-ENERGY BUILDINGS: STATUS AND PERSPECTIVES", Journal of Green Building vol 6

[2]. "Lab designed to study green energy technologies completed at UNT".University of North Texas. 10 April 2012. Retrieved 25 June 2014.

[3]. Paul A. Torcellini, Drury B. Crawley. "Understanding Zero Energy Buildings", ASHRAE Journal, September 2006

[4]. Brian Milani.( 2005) "Building Materials in a Green Economy"

[5]. David Rousseau. "Environmentally friendly building material (pp 60-80)".Vol-1. Sustainable Built environment.

[6]. Davis Langdon (2009). "Cost and benefits of achieving green building",.

[7]. Green Build/Prop. (February 2009) "Scoping study into future opportunities for sustainable building products"

[8]. Invest Northern Ireland (February 2009) "Scoping Study Into Future Market Opportunities For Sustainable Building Products".

[9]. Jones Lang, lasallemeghraj. "Cost efficiency of Green buildings in India(pp 1-8,)" "Greenomics"

[10]. Kabir Malik and Maureen Cropper.(2009)“The Hidden cost of power"

[11]. Ministry of non-conventional energy sources. (2008). Book "Energy efficient buildings in India" Green Buildings Anthology

[12]. US Dept. of Energy by National Renewable Energy Lab. (July 2000) "Elements of an Energy efficient house". Energy efficiency and Renewable Energy. 